ARTIGO ORIGINAL

\title{
Turismo de base comunitária: \\ análise quanto às interferências do turismo de pesca no baixo Rio Branco, Roraima, Brasil
}

Community Based Tourism: review as to fishing tourism interference in the lower Rio Branco, Roraima, Brazil

Turismo de base comunitaria: análisis de la interferencia de turismo de pesca en el bajo Rio Branco

http://dx.doi.org/10.18472/cvt.16n2.2016.1164

Luciana de Souza Vitório 〈 luciana.vitorio@ifrr.edu.br > Instituto Federal de Roraima, IFRR, Brasil.

Sílvio Luiz Gonçalves Vianna〈slgvianna@ucs.br >

Universidade de Caxias do Sul, UCS, Brasil.

CRONOLOGIA DO PROCESSO EDITORIAL

Recebimento do artigo: 03-nov-2015

Aceite: 14-ago-2016

FORMATO PARA CITAÇÃO DESTE ARTIGO

VITÓRIO, L. S.; VIANNA, S. L. G. Turismo de base comunitária: análise quanto às interferências do turismo de pesca no baixo Rio Branco, Roraima, Brasil. Caderno Virtual de Turismo. Rio de Janeiro, v. 16, n. 2, p. 126-149, ago. 2016.

REALIZAÇÃO

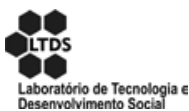

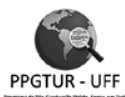

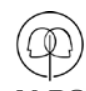

APOIO INSTITUCIONAL

EDIÇÃO

PATROCÍNIO

COPPE

UFR] 


\section{RESUMO}

A região do Baixo Rio Branco está localizada ao sul do município de Caracaraí, no estado de Roraima, Brasil, onde há mais de uma década vem se desenvolvendo atividades de turismo de pesca, dentro da Área de Proteção Ambiental (APA) Xeriuini. A Vila Terra Preta está inserida nessa APA e tem seus moradores contratados para trabalharem como guias de pesca na atividade turística. Este estudo tem como objetivo: analisar, sob a ótica da comunidade de Vila Terra Preta, as interferências da atividade de turismo de pesca na região do Baixo Rio Branco, município de Caracaraí. Fez-se uso de questionário como instrumento de pesquisa exploratória com abordagem quantitativa e qualitativa, chegando a resultados que mostram interferências positivas quanto à geração de empregos e complemento de renda, mesmo que esses postos de trabalhos sejam temporários. Mas, por outro lado interferências prejudiciais à população de peixes devido aos equipamentos usados por turistas/pescadores, percebidas por alguns moradores. Também o turismo não tem contribuído para melhorias na infraestrutura da comunidade e em relação à gestão os entrevistados consideram-se excluídos dos processos de decisão e participação na organização da atividade turística.

Palavras-chave: Turismo. Participação Comunitária. Pesca Esportiva. Roraima. Brasil.

\section{ABSTRACT}

The lower Rio Branco region is located south of the city of Caracarai in the state of Roraima, Brazil, where for over a decade has been developing fishing tourism activities within the Environmental Protection Area (EPA) Xeriuini. The Vila Terra Preta is inserted in this EPA and its residents have hired to work as fishing guides in the tourism industry. This study aims: to analyze, from the perspective of Vila Terra Preta community, interference fishing tourism activity in the Lower Rio Branco region, municipality of Caracaraí. There was questionnaire use as exploratory research instrument with quantitative and qualitative approach, reaching results showing positive interference on the generation of jobs and income supplement, even if these jobs are temporary jobs. But on the other hand harmful interference to the fish population due to the equipment used by tourists / fishermen, perceived by some locals. Tourism does not have also contributed to improvements in community infrastructure and on the management respondents consider themselves excluded from decision-making and participation in the organization of tourism.

Keywords: Tourism. Community Participation. Sport Fishing. Roraima. Brazil.

\section{RESUMEN}

La región del bajo Río Branco se encuentra al sur de la ciudad de Caracaraí en el estado de Roraima, Brasil, donde desde hace más de una década se ha venido desarrollando actividades de turismo pesquero dentro del Área de Protección Ambiental (APA) Xeriuini. El Vila Terra Preta se inserta en este APA y sus residentes han contratado para trabajar como guías de pesca en la industria del turismo. Este estudio tiene como objetivo: analizar, desde la perspectiva de la comunidad de Vila Terra Preta, la actividad turística de la pesca injerencia en la región del Bajo Río Branco, municipio de Caracaraí. Hubo utilización cuestionario como instrumento de investigación exploratorio con enfoque cuantitativo y cualitativo, alcanzando resultados que muestran interferencia positiva en la generación de puestos de trabajo y suplemento de ingresos, incluso si estos puestos de trabajo son empleos temporales. Pero por otro lado interferencias perjudiciales para la población de peces debido a los equipos utilizados por los turistas / pescadores, percibido por algunos lugareños. Turismo no tiene también contribuyó a la mejora de la infraestructura comunitaria y de los encuestados de gestión se consideran excluidos de la toma de decisiones y la participación en la organización del turismo.

Palabras claves: Turismo. Participación Comunitaria. Pesca Deportiva. Roraima. Brasil. 


\section{INTRODUÇÃO}

No Brasil, o estudo do turismo de base comunitária começou a ganhar evidência a partir de meados da década de 1990, no âmbito dos Encontros de Turismo de Base Local (ENTBL). As edições desse encontro viabilizaram a consolidação de redes não formais de pesquisadores engajados nessa reflexão (IRVING, 2009).

Com base na compreensão de que o turismo de base comunitária considera o desenvolvimento local, a comunidade, a gestão participativa, o protagonismo social e diante da situação favorável à pesquisa, percebida em visita realizada na região do Baixo Rio Branco no ano de 2012, mais precisamente na Vila Terra Preta, município de Caracaraí - Roraima, Brasil. Município que possui uma história singular e no qual a atividade turística vem sendo concebida de maneira exógena, surgiu o seguinte problema de pesquisa: Quais as interferências causadas pela atividade de turismo de pesca praticada na região do Baixo Rio Branco, sob a ótica da comunidade da Vila Terra Preta - Município de Caracaraí-RR?

No intuito de tentar encontrar respostas para esse problema de pesquisa e considerando que o turismo de base comunitária pode trazer a possibilidade de maior envolvimento desses moradores na atividade, se a comunidade assim o quiser. O presente estudo tem como principal objetivo analisar, sob a ótica da comunidade de Vila Terra Preta, as interferências da atividade de turismo de pesca na região do Baixo Rio Branco, município de Caracaraí, Roraima.

Para alcançar o objetivo proposto, buscou-se inicialmente identificar o perfil dos moradores da comunidade de Vila Terra Preta, com o intuito de conhecer melhor quem são os moradores da região. Em seguida foi avaliado qual o estágio de desenvolvimento da atividade de turismo de pesca praticada na região do Baixo Rio Branco, visando compreender qual a articulação existente entre o poder público e a comunidade.

Na sequência foram identificadas as interferências causadas pela atividade de turismo de pesca que afetam as condições de vida dos residentes da Vila Terra Preta, analisando tanto os aspectos positivos quanto negativos envolvidos. E, por fim, analisou-se a receptividade e o envolvimento dos autóctones em relação às atividades desenvolvidas pelos operadores de turismo na região.

Ressalta-se que este estudo utiliza o termo "interferência" em detrimento de impacto, acompanhando uma corrente de estudos oriundos do Programa de Pós-Graduação em Turismo da Universidade de Caxias do Sul - Camargo, Machiavelli e Ramos (2011), Ramos (2012), Marsilio (2014) - que destacam a conotação negativa que esse segundo termo carrega, enquanto que o termo "interferências" abarcaria as interações da atividade de turismo dentro do processo de trocas entre os envolvidos bem como no ambiente.

Com o intuito de trazer reflexões sobre o envolvimento e a participação comunitária na atividade turística da região, esta pesquisa se torna relevante ao abordar como a comunidade é afetada pela atividade, em três aspectos: a) econômico - a compreensão da situação econômica decorrente do contrato de serviços entre os operadores e os moradores requisitados para o trabalho; b) social - a compreensão da condição social da comunidade como um todo, uma vez que as interferências afetam não somente os moradores contratados, mas também suas famílias e o modo de vida destas; c) ambiental - a compreensão da interação resultante da atividade praticada no meio ambiente natural e das possíveis modificações que essa prática pode trazer para a comunidade local. 


\section{TURISMO DE BASE COMUNITÁRIA}

O turismo de base comunitária ou turismo comunitário surgiu como uma alternativa ao turismo convencional, apesar de ser, em grande parte, dependente da mesma infraestrutura turística utilizada pelo turismo convencional, especialmente em termos de transporte (GOODWIN; SANTILLI, 2009). Esse tipo de turismo busca se contrapor ao turismo massificado, requer menor densidade de infraestrutura e serviços, e valoriza uma vinculação situada nos ambientes naturais e na cultura local (BURSTYN; BARTHOLO; DELAMARO, 2009, p. 86).

No entendimento de Maldonado (2005), a dinâmica social que está impulsionando muitas comunidades por meio da atividade turística, representa uma oportunidade para fortalecer as estruturas democráticas e as práticas solidárias, tendo, por exemplo, os processos de consulta e participação dos seus membros na tomada de decisão.

Seguindo a mesma linha de raciocínio, a WWF-Internacional (2001), em seus estudos de base para a certificação do turismo sustentável no Brasil, alerta para o fato de que, a atividade turística desordenada provoca desequilíbrios socioambientais e econômicos. Porém, afirma que o turismo comunitário é o único tipo de turismo cujo controle efetivo está nas mãos da comunidade e que isso ocorre em decorrência do envolvimento participativo desde a concepção inicial dos projetos, uma vez que "[...] projetos de turismo devem proporcionar a maior parte de seus benefícios para as comunidades locais” (p. 2).

Percebe-se que a participação é o elemento-chave para que os objetivos do turismo comunitário sejam efetivados, e para que os benefícios cheguem realmente à comunidade. A participação local não deve ser confundida com modelos daquele tipo que "informa" a população sobre as ações políticas. Ao contrário, são as ações políticas que fundamentam o envolvimento real de todos os atores sociais no processo de gestão, pois, somente por meio do engajamento efetivo poderão participar do planejamento e das tomadas de decisão, referentes a seu patrimônio, sendo o grau de comprometimento desses atores o fator determinante para a inclusão pretendida (SILVEIRA, 1999).

Seja qual for a forma de organização das comunidades ou das parcerias firmadas, é preciso considerar, no planejamento, as vantagens e as desvantagens desse modelo de gestão. Irving (2009) considera um equívoco imaginar o TBC como uma alternativa em substituição ao turismo de massa, no que diz respeito à geração de receita, não sendo este o objetivo de iniciativas dessa natureza.

Os estudos de Burstyn, Bartholo e Delamaro (2009) destacam os benefícios do turismo comunitário: "[...] esse turismo respeita as heranças culturais e tradições locais, podendo servir de veículo para revigorá-las e mesmo resgatá-las. Tem centralidade em sua estruturação e o estabelecimento de uma relação dialogal e interativa entre visitantes e visitados" (p. 86).

Para Fortunato e Silva (2013) seria um equívoco continuar difundindo uma ideologia "romantizada" do ideal comunitário, tornando-se relevante pensar nos possíveis conflitos e nas ambivalências existentes para que ocorram avanços conceituais, sem desconsiderar o aspecto fundamental que proporciona às comunidades receptoras, a ampliação da sua participação democrática e das melhorias socioculturais por meio do desenvolvimento local.

Irving (2009) observa que, embora frequentemente atores externos à atividade funcionem como indutores, se a iniciativa não tiver motivação endógena e expressar o desejo dos grupos sociais locais, ela certamente não atenderá às demandas de desenvolvimento local e nem contribuirá para o protagonismo social. Pensando dessa maneira, optou-se neste estudo pela escolha do turismo de pesca como elemento impulsionador da atividade na região, que possui a expertise necessária para desenvolvê-lo. 


\section{TURISMO DE PESCA}

Tradicionalmente, por definição, a pesca é o ato de extrair organismos aquáticos, tanto em águas continentais (rios, barragens, lagos, lagoas e açudes) quanto em águas marinhas (MTUR, 2010). Com o passar dos anos, o desenvolvimento da atividade de pesca permitiu classificá-la em categorias conforme suas características. Uma dessas categorias é a pesca amadora que é praticada por lazer ou esporte, ou seja, o praticante não depende dela para sobreviver. É uma atividade que se popularizou com o passar dos anos (MTUR, 2010).

Martos e Martos (2005) mencionam as diferenças entre a pesca amadora e a pesca esportiva em conformidade com a Associação Brasileira de Pesca Esportiva (ABPE), a primeira "[...] praticada pela grande maioria dos pescadores, diferencia-se da pesca profissional por seu caráter não comercial” (p.383). Tendo como objetivo proporcionar prazer em contato com a natureza e momentos de relaxamento e contemplação. A pesca esportiva “[...] é uma atividade competitiva entre pessoas ou grupos” (p.383).

A construção do conceito de Turismo de Pesca fundamenta-se em dois aspectos principais: os movimentos turísticos que ocorrem em territórios específicos, em razão da disponibilidade de espécies de peixes; e o perfil do turista de pesca. Esse perfil é definido pela motivação, que determina a evolução da atividade de pesca como opção de lazer, caracterizando-a pelo usufruto dos recursos naturais de forma sustentável, de acordo com as peculiaridades das duas atividades - pesca e turismo - e com as legislações que as regem (MTUR, 2010).

Assim, define-se: “[...] turismo de pesca compreende as atividades turísticas decorrentes da prática da pesca amadora" (MTUR, 2010, p. 28). Para entendimento dessa definição, é necessário compreender o significado do termo "atividades turísticas", por ser considerado fundamental nessa definição.

As "atividades turísticas" são entendidas como o conjunto de atividades e serviços gerados em função do turismo, no caso do turismo de pesca, sendo a viabilização da prática da pesca amadora aos indivíduos que se deslocam a partir de sua residência habitual. Esse conjunto envolve a oferta de equipamentos, produtos e serviços, tais como: operação e agenciamento turístico; serviços de transporte; meios de hospedagem; serviços de alimentação; recepção e condução; eventos; material para pesca; e outras atividades complementares que existam em função do turismo de pesca (MTUR, 2010).

Martos e Martos (2005) consideram que o turismo de pesca é uma atividade importante, porém, regulamentada, basicamente, na esfera ambiental. Em relação ao turismo, o aporte legal está na Lei n. 11.771 de 2008 - Política Nacional de Turismo - que define as atribuições do Governo Federal no planejamento, desenvolvimento e estímulo ao setor turístico, em que alguns de seus objetivos são: desenvolver, ordenar e promover os diversos segmentos turísticos; propiciar a prática de turismo sustentável nas áreas naturais; preservar a identidade cultural das comunidades e populações tradicionais eventualmente afetadas pela atividade turística; propiciar a competitividade do setor por meio da melhoria da qualidade, eficiência e segurança na prestação dos serviços; estabelecer padrões e normas de qualidade, eficiência e segurança na prestação de serviços por parte dos operadores, empreendimentos e equipamentos turísticos (MPA, 2010).

Dessa maneira, para melhor compreender as consequências às quais a comunidade local está sujeita, em razão do desenvolvimento das atividades turísticas, é preciso investigar como a atividade interfere no ambiente e modo de vida das pessoas. 


\section{INTERFERÊNCIAS DA ATIVIDADE TURÍSTICA NAS COMUNIDADES RECEPTORAS}

As interferências da atividade turística estão relacionadas a um conjunto de modificações ou consequência de eventos, provocados pelo desenvolvimento do turismo nas localidades receptoras (RUSCHMANN, 1999).

O termo "impacto" tem sido usado com bastante frequência nos meios de comunicação mais diversos, sem que se tenha uma definição precisa de seu significado. Erroneamente, a tendência no uso desse termo está associada apenas a uma reação negativa, o que tem sido muito recorrente, mas o impacto também pode ser considerado positivo (VASCONCELOS; CORIOLANO, 2008).

Santana (2009, p. 148) sustenta que o termo "impacto" carrega "[...] conotação de indesejável, de choque, de avanço de uns sobre os outros", enquanto o termo "interferência” abarcaria "[...] os resultados de um encontro, nem sempre expressos como positivos ou negativos para o conjunto de atores".

No caso deste estudo, adota-se o termo "interferência" por reconhecer a complexa relação dos envolvidos, mas assumindo que, mesmo desproporcionalmente, todos os envolvidos possuem responsabilidade e autonomia nesse processo de troca e por considerar um termo de uso mais pertinente em relação ao estudo do turismo, uma vez que se trata de uma atividade humana, o que predispõe em maior ou menor grau algum tipo de intervenção no ambiente onde será desenvolvida a atividade.

Do ponto de vista econômico, as interferências provenientes da atividade turística segundo a OMT (2003), podem ser vistas em termos de: 1 - empregos e renda oriundos do trabalho no setor turístico; 2 - estímulo ao empresariado local, por meio do estabelecimento de empreendimentos turísticos locais, e desenvolvimento de habilidades para o trabalho com o turismo, que podem ser transferidas a outras atividades; 3 - ganhos em câmbio estrangeiro, no âmbito nacional, regional e local; 4 - contribuições aos rendimentos do governo, inclusive em âmbito local, caso haja impostos relacionados à atividade; e 5 - incentivo para a expansão de outras atividades econômicas locais (agricultura, pesca e artesanato).

O estudo de Oliveira e Teixeira (2005) analisou a contribuição socioeconômica das empresas ligadas à atividade turística e verificou que a maior contribuição destas é a geração de empregos diretos, mesmo havendo os empregos temporários na alta estação.

Cooper et al. (2001) ressaltam que as análises econômicas tendem a avaliar o turismo por uma perspectiva unilateral, ressaltando o lado positivo dessa atividade, mesmo sabendo que há diversas consequências econômicas negativas, como: a sazonalidade; os trabalhos temporários; e a inflação. Mas, por outro lado, os estudos dos impactos ambientais, sociais e culturais tendem a enfocar mais as despesas inerentes ao desenvolvimento turístico, mesmo sabendo que tais situações podem ser positivas, como proteção de sítios naturais e recursos culturais, educação ambiental e elevação da autoestima local.

Vasconcelos e Coriolano (2008) afirmam que as consequências socioambientais são relativas às grandes mudanças que ocorrem na natureza e também na sociedade. É necessário o estabelecimento de critérios para definir se as ações humanas ou as atividades econômicas têm em seu conjunto resultados positivos ou negativos.

Sperb e Teixeira (2006), ao analisarem a perspectiva dos gestores públicos sobre a sustentabilidade ambiental, consideraram que é preciso o estabelecimento de uma política que oriente ações de saneamento básico, educação ambiental, legislação específica e capacidade de carga. 
Ao analisarem os impactos do Programa Aventura Segura (PAS) nas atividades de turismo de aventura, Machado, Bazotti e Vianna (2014) verificaram que a parceria entre o poder público e a iniciativa privada pode contribuir para estimular a capacidade empresarial das famílias da comunidade e permitir maior envolvimento e um desenvolvimento endógeno que viabilize a recuperação e valorização da cultura local. Para isso, os autores consideram que o turismo precisa estar integrado às demais atividades da comunidade, valorizando seu meio de vida tradicional baseado na agricultura e na pesca, por exemplo.

Por outro lado, diversas consequências negativas podem ser geradas se a atividade do turismo não for bem planejada, desenvolvida e gerenciada: 1 - poluição da água (rios, lagos, igarapés, etc.); 2 - poluição sonora; 3 - paisagem suja, um problema resultante do descaso com o lixo; e 4 - desequilíbrio ecológico e perturbação da vida selvagem pelo contato excessivo, e às vezes, incorreto (OMT, 2003). Esses fatores destacam-se entre outros decorrentes da prática turística inadequada. Colocando a comunidade em foco, Silva e Maia (2008) analisaram a sua percepção quanto aos benefícios da atividade turística. Expuseram aspectos positivos e negativos: uma pequena parte dos moradores locais percebeu um impulso na economia local e a preservação ambiental, porém, outros não quiseram se posicionar sobre o assunto. Os autores consideram que esse fato está relacionado ao nível de informação ou ao grau de aproveitamento financeiro por parte dos moradores e sugerem a definição de diretrizes claras, em conjunto, pela população, setor privado e setor público.

Essas interferências somente serão amenizadas mediante a prática de um turismo sustentável que considere em seu planejamento ações minimizadoras. As comunidades receptoras da destinação turística precisam estar inseridas na discussão sobre esse tipo de turismo, para isso é de fundamental importância investigar sobre o que a comunidade pensa a respeito das atividades turísticas, que conhecimentos ela detém sobre essas atividades e se elas estão dispostas a trabalhar com essas atividades.

\section{METODOLOGIA}

Neste estudo foi realizada uma pesquisa exploratória de caráter descritivo que, segundo Köeche (2011, p. 126) é um tipo de pesquisa que tem como objetivo fundamental "[...] descrever ou caracterizar a natureza do fenômeno”. É um processo de investigação em que são identificadas e apontadas as características do fenômeno.

A pesquisa tem abordagem qualitativa e também quantitativa, visto que a análise e a interação de dados que foram coletados se deram sob essas perspectivas. Para Poupart et al. (2008, p. 129), dados quantitativos podem ser analisados qualitativamente, bem como os dados qualitativos "[...] podem ser analisados por meio de uma aparelhagem destinada a quantificação dos dados”, e também ampliam as possibilidades de entendimento quanto ao fenômeno que é foco do estudo.

Como recursos metodológicos utilizaram-se: pesquisa documental e aplicação de questionários. A pesquisa documental refere-se à necessidade de reunir informação sobre a região onde está situada a Vila Terra Preta, objeto deste estudo. A aplicação de questionários mostrou-se essencial para a coleta de dados primários que viabilizaram aos pesquisadores o alcance dos objetivos específicos definidos para esta pesquisa. 
A pesquisa foi dirigida aos moradores da Vila Terra Preta que, de acordo com as informações obtidas na Secretaria Municipal de Saúde, possui população estimada em 149 habitantes sendo 55 com faixa etária de 0 a 14 anos e 94 com faixa etária a partir de 15 anos, residindo na comunidade um clã de 36 famílias.

O questionário teve como base o estudo de Dall'Agnol (2009) e foi elaborado para identificar dados como idade, gênero, escolaridade, estado civil, ocupação, renda familiar, naturalidade, visando traçar o perfil dos sujeitos (moradores), além de conter 48 afirmações a serem analisadas de acordo com a escala Likert, utilizada de maneira inversa à tradicional, considerando a seguinte variação: 1 - concordo plenamente; 2 - concordo; 3 - concordo parcialmente; 4 - discordo parcialmente; 5 - discordo; e 6 - discordo totalmente. Destaca-se que o período da visita coincidiu com a data de início da temporada de pesca.

Os dados da coleta foram tabulados com auxílio do software Microsoft Office Excel, usado para a elaboração das fórmulas estatísticas simples (média e desvio padrão) utilizadas para a análise estatística descritiva. Assim, na análise dos resultados a média apontará o grau de concordância dos sujeitos de pesquisa, quanto menor a média maior o grau de concordância e quanto maior a média menor o grau de concordância. O desvio padrão indica a homogeneidade e a heterogeneidade da amostra, quanto menor o desvio padrão mais homogênea é a amostra e quanto maior o desvio padrão, mais a amostra é heterogênea.

\section{ANÁLISE DE DADOS}

Dos moradores entrevistados, exatos 50\% são do sexo masculino e $50 \%$ do sexo feminino. Quanto à faixa etária, $29 \%$ dos entrevistados têm de 18 a 27 anos, $18 \%$ de 28 a 37 anos, 22\% de 38 a 47 anos, $7 \%$ de 48 a 57 anos e $11 \%$ de 58 a 65, apenas $9 \%$ têm mais de 65 anos de idade, isso indica uma população jovem em idade produtiva. Com relação ao estado civil, $54 \%$ dos entrevistados estão casados e têm filhos e $40 \%$ estão solteiros. Quanto à quantidade de filhos, $9 \%$ dos entrevistados tem mais de oito filhos.

Quanto ao nível de escolaridade, a maioria (56,58\%) possui somente o Ensino Fundamental Incompleto, com apenas 5,26\% tendo completado o Ensino Médio Completo. É interessante destacar que as séries mais mencionadas pelos entrevistados que declararam ter cursado o Ensino Fundamental Incompleto foram a $3^{\mathrm{a}}, 5^{\mathrm{a}}$ e $1^{\mathrm{a}}$ séries. Também é interessante ressaltar que $15,79 \%$ dos respondentes não possuem Alfabetização, apesar de estar em idade adulta, isso indica a necessidade de atenção, por parte dos órgãos educacionais (municipais e estaduais), para ações que contemplem a alfabetização de jovens e adultos.

Com relação à ocupação e trabalho, 53\% dos respondentes afirmaram que trabalham, realizam alguma atividade laboral, já 47\% declararam não ter ocupação, porém, comentaram que trabalham em atividades como plantação e colheita (roça), coleta de sementes para artesanato, coleta de castanha e que declaram não ter ocupação por não possuírem nenhum vínculo empregatício. Curiosamente, alguns respondentes que declararam ter ocupação fizeram o mesmo comentário: "trabalho só na roça" ou "trabalho só no turismo", mesmo não possuindo nenhum vínculo empregatício.

Quando questionados sobre a dependência econômica da atividade turística, 80\% responderam que não dependem do turismo. Alguns desses entrevistados, mesmo exercendo alguma função no turismo, declararam não depender da atividade, complementaram a resposta afirmando que fora da temporada de pesca se ocupam em outra atividade. Apenas $20 \%$ consideram depender da atividade do turismo, apesar da sazonalidade. 
No tocante à renda familiar dos entrevistados, observa-se que 63\% declararam ter renda de até 2 (dois) salários mínimos, considerando a definição equivalente a $\mathrm{R} \$ 678,00$ (seiscentos e setenta e oito reais, piso salarial vigente durante o período de coleta de dados), e 35\% afirmaram não ter renda. Quanto a essas informações foi possível entender, no ato da entrevista, o seguinte quadro: dos entrevistados que declaram ter renda, alguns são funcionários públicos, prestam serviço na educação, saúde, fornecimento de energia e transporte; outros afirmaram que trabalham "só na roça" não possuindo nenhum vínculo empregatício.

Vale ressaltar que a maioria dos respondentes que afirmaram receber até dois salários mínimos enfatizaram, no ato da entrevista, que recebem apenas 01 salário mínimo, porém, no questionário não havia a opção de marcar essa informação.

Quanto à naturalidade dos respondentes verificou-se que 66\% são nascidos no município de Caracaraí. Do total de respondentes, $8 \%$ afirmam terem nascido na própria Vila Terra Preta e $20 \%$ afirmam terem nascido nos vilarejos às margens dos rios da região. Conforme relatos dos moradores, algumas parturientes são assistidas com parto natural, na própria localidade. Ressalta-se que o hospital mais próximo da Vila, fica a 12 horas de barco. É interessante observar que 32\% dos entrevistados afirmaram ter nascido no estado do Amazonas com a ressalva de que apenas nasceram, pois na região há falta de recursos médicos e, em alguns casos, são necessários deslocamentos aos centros urbanos mais próximos.

\section{Estágio de Desenvolvimento da Atividade de Turismo de Pesca na Área de Proteção Ambiental Xeriuini - Região do Baixo Rio Branco}

A visualização do cenário turístico de pesca na APA Xeriuini no Baixo Rio Branco pode ser feita sob dois aspectos, a gestão municipal do turismo e a atividade operacional da empresa de turismo atuante na região. O principal órgão público para assuntos de turismo em Caracaraí é a Secretaria Municipal de Meio Ambiente e Turismo, que tem sob sua responsabilidade a fiscalização ambiental e a gestão do turismo de pesca esportiva.

O município possui um cadastro de empresas credenciadas que podem atuar na atividade turística, mediante a solicitação de licença para a operação. Para tecer um panorama do atual estágio de desenvolvimento do turismo de pesca no Baixo Rio Branco foi interessante observar a legislação pertinente à atividade. Com relação à legislação municipal existente no ano de 1999, o Decreto n. 25, de 08 de dezembro, instituiu a Área de Proteção Ambiental (APA) Xeriuini, “[...] com o objetivo de conservar as áreas representativas dos ecossistemas ali existentes e promover o desenvolvimento social e econômico das comunidades de povos tradicionais nela encontrados" (CARACARAÍ, 1999).

Esse decreto versa também sobre a celebração de convênios entre o Departamento Especial de Meio Ambiente (Dematur) e instituições públicas ou privadas legalmente constituídas, objetivando desenvolver atividades compatíveis com a finalidade da APA Xeriuini. Outro aporte legal sobre a atividade na região é a Lei municipal n. 378, de 18 de novembro de 2002, que dispõe sobre a licença de pesca esportiva na APA Xeriuini.

Após o levantamento dessas regulamentações, é importante identificar características da empresa que, atualmente, tem concessão para operar a atividade de turismo de pesca na área de estudo. A empresa que atua na região da Vila Terra Preta - APA Xeriuini é a River Plate Pesca. Essa operadora de turismo de pesca faz parte do grupo Liga de Ecopousadas da Amazônia, com sede na cidade de Manaus, estado do Amazonas, constituída desde o ano de 1992. A operadora River Plate é uma das empresas credenciadas no órgão ambiental municipal e tem zona de pesca demarcada no Baixo Rio Xeriuini, dentro da APA Xeriuini. 
Conforme as informações obtidas com o secretário municipal, a Prefeitura de Caracaraí fez concessão de uso dos recursos dessa área que foram demarcadas para a pesca esportiva com a finalidade de receber em contrapartida ações para sua preservação.

O fato da empresa não possuir domicílio fiscal em Caracaraí, município-sede da Área estudada, o deixa em desvantagem quanto à arrecadação de impostos sobre os serviços, além de que toda operação do serviço comercializado que é organizado a partir de Manaus, deixa o estado de Roraima e o município de Caracaraí prejudicados como receptores da demanda de turistas, conforme sustenta Nogueira et al. (2006).

\section{Interferências da Atividade de Turismo de Pesca}

Ao analisar as informações a seguir, busca-se a compreensão, na visão dos moradores, de como a atividade turística vem interferindo na condição econômica e socioambiental da comunidade. Nessa direção, foram considerados os comentários e justificativas dos respondentes registrados no ato da entrevista.

O Quadro 1 dispõe as informações de ordem econômica entendidas na sua relação com a atividade do turismo vivenciada pela comunidade em estudo e que visam proporcionar a oportunidade de entender se a relação ocorre de maneira positiva ou negativa.

Quadro 1 - Informações sobre visão dos moradores em relação ao turismo e economia

\begin{tabular}{|c|c|c|}
\hline Interferências na Economia & Média & Desvio Padrão \\
\hline $\begin{array}{l}1 \text { - As pessoas da região têm mais dinheiro para gastar } \\
\text { graças ao turismo de pesca. }\end{array}$ & 2,658 & 1,18 \\
\hline $\begin{array}{l}2 \text { - } 0 \text { turismo de pesca gera empregos na minha } \\
\text { localidade. }\end{array}$ & 2,303 & 1,05 \\
\hline 3- 0 turismo de pesca gera empregos na minha região. & 2,329 & 0,93 \\
\hline 4- 0 turismo de pesca gera impostos para o estado. & 3,776 & 1,53 \\
\hline 5- 0 turismo de pesca gera impostos para o município. & 2,658 & 1,23 \\
\hline $\begin{array}{l}6 \text { - } 0 \text { turismo de pesca ajuda a aumentar a renda familiar } \\
\text { dos moradores da região. }\end{array}$ & 2,316 & 0,88 \\
\hline $\begin{array}{l}7-0 \text { turismo na minha região faz com que existam postos } \\
\text { de trabalho muito desejáveis. }\end{array}$ & 3,289 & 1,65 \\
\hline $\begin{array}{l}8-0 \text { turismo tem feito com que subam os preços na } \\
\text { minha região. }\end{array}$ & 4,145 & 1,24 \\
\hline $\begin{array}{l}9 \text { - Os benefícios derivados do turismo são mais } \\
\text { importantes para minha região do que os benefícios } \\
\text { derivados da agricultura ou da pesca artesanal. }\end{array}$ & 3,776 & 1,64 \\
\hline $\begin{array}{l}10 \text { - } 0 \text { turismo de pesca é uma das principais fontes de } \\
\text { renda da minha região. }\end{array}$ & 3,211 & 1,45 \\
\hline
\end{tabular}

Fonte: Pesquisa de Campo (2014).

Analisando o resultado de concordância parcial $(2,658)$ com a afirmação de que as pessoas da região têm mais dinheiro para gastar graças ao turismo de pesca, entende-se que isso ocorra em função do fato da sazonalidade da atividade e também por valorizarem as outras atividades exercidas por elas. Um exemplo é o comentário do respondente que justificou sua resposta com o seguinte argumento: “[...] há circulação 
de dinheiro também na temporada da castanha. Ganhamos dinheiro com a castanha também". Outro exemplo que corrobora a constatação feita é o seguinte comentário feito por outro respondente: "[...] na temporada de pesca, os que trabalham têm uma renda extra". Tal comentário deixa transparecer que nem todos se beneficiam das atividades turísticas.

Sobre a geração de empregos na localidade e região, houve predominância quanto a concordar $(2,303)$ com a afirmação de que o turismo ajuda na oferta de empregos locais, na visão dos entrevistados. Quanto à geração de impostos, os respondentes discordam parcialmente $(3,776)$ já que os impostos são gerados em âmbito estadual e concordam parcialmente $(2,658)$ que o turismo gera impostos para o município, o que é justificado pelo fato de a maior empresa em atividade na região ter sua sede no estado do Amazonas.

Quanto ao assunto renda familiar, os entrevistados concordam $(2,316)$ que o turismo de pesca ajuda a aumentar a renda dos moradores da região, concordam parcialmente que os postos de trabalho gerados pelo turismo são desejados pelos moradores.

Sobre a relação do turismo com o aumento de preços na região, os respondentes discordam parcialmente $(4,145)$, ressaltam que pelo fato do isolamento é comum a chegada dos produtos com o preço mais elevado e isso não tem relação com o turismo, havendo a possibilidade, inclusive, de com o incremento da atividade turística, haver o aumento na quantidade de transportes regulares, o que poderia contribuir para reduzir o preço das mercadorias que são trazidas até a Vila Terra Preta.

No tocante aos benefícios do turismo serem mais importantes para a região do que os benefícios gerados pela agricultura e pesca artesanal, os moradores da Vila Terra Preta também discordam parcialmente $(3,776)$. Concordam parcialmente $(3,211)$ que o turismo de pesca é uma das principais fontes de renda da região, por se tratar de uma atividade temporária (apenas cinco meses).

É possível constatar que as interferências do turismo na economia da região, sob a ótica dos moradores, se baseiam na oferta de empregos temporários, não somente para os moradores da localidade, mas também para os moradores das vilas vizinhas; na circulação de moeda devido aos salários recebidos pelos moradores e somente a isso, pois para a execução do serviço a empresa tem seus fornecedores na cidade de Manaus, nada é adquirido na região, não gerando renda nesse aspecto.

Contudo, os entrevistados não consideram o turismo como a principal de fonte de renda da região, observando que apenas $20 \%$ deles afirmaram que dependem economicamente do turismo. Também não consideram os benefícios advindos do turismo como sendo mais importantes do que os benefícios gerados pela agricultura e pesca, embora avaliem que o turismo complementa a renda familiar e gera impostos para o município.

No tocante à renda, toma-se como exemplo o caso de uma entrevistada que trabalhou como auxiliar de cozinha e recebeu na última temporada em que trabalhou (começo do ano de 2013), para uma das empresas que atuam na região, $\mathrm{R} \$ 60,00$ para cada dia trabalhado (6 dias), totalizando um valor de $\mathrm{R} \$ 360,00$. Porém, como são contratados em regime de rodízio, pode ser que ela trabalhe apenas esses seis dias no mês, e por isso ela perceber que os benefícios econômicos do turismo sejam apenas um complemento na renda familiar. Segundo os relatos da entrevistada, os que trabalham como "piloteiros" ganham bem mais, inclusive nas gorjetas.

Oliveira e Teixeira (2005) concluíram em seu estudo sobre a contribuição socioeconômica do setor privado na atividade turística que os salários pagos pela atividade no município que pesquisaram encontram-se na faixa de 1,0 a 1,47 salário mínimo, e que isso possibilita somente a manutenção de condições 
mínimas de sobrevivência e não uma interferência que modifique a qualidade de vida da população local. No presente estudo, observou-se que os salários pagos, por vezes, estão abaixo de um salário mínimo e todos os empregos oferecidos são meramente informais, fazendo com que a contribuição do turismo, no aspecto econômico, seja contrária ao objetivo de promover o desenvolvimento social e econômico das comunidades de povos tradicionais da região, como trata o art. $1^{\circ}$ do Decreto n. 25/1999 que instituiu a Área de Proteção Ambiental (APA) Xeriuini.

Observa-se ainda que o fato da empresa de maior atuação na região estar constituída em outro estado faz com que impostos referentes aos serviços sejam gerados para o município/estado onde está sediada. Conforme relatos dos moradores, a empresa paga diretamente à comunidade um valor por temporada e de acordo com gestor municipal a empresa paga ao município as taxas de licenças de pesca.

A receita dessas licenças de pesca, segundo o art. $2^{\circ}$ da Lei n. 378 de 18/11/2002 que institui a licença de pesca na APA Xeriuini, destinar-se-ia à organização e custeio das atividades de monitoramento e fiscalização ambiental, porém, de acordo com os relatos dos moradores isso não tem acontecido e os conflitos existentes há mais de 15 anos sequer foram amenizados, por falta de monitoramento e fiscalização.

Tendo em vista que a atividade vem sendo bem executada pela empresa operadora e que os turistas sentem-se satisfeitos após vivenciar a experiência da pesca em uma região preservada; considerando ainda que o pagamento pelos serviços é efetuado, geralmente antes da execução destes; e que o turismo na região é uma atividade que movimenta cifras bem elevadas, é notório que o poder público e a comunidade necessitam, primeiramente, de organização, pois sem a definição de um plano que pondere a sazonalidade da atividade, as necessidades e a opinião dos moradores locais, a gestão se tornará cada vez mais inadequada, prejudicando ainda mais a população que precisa, pelo menos, melhorar sua condição básica de vida.

Quanto a isso, passa-se agora a analisar conforme o Quadro 2, a visão dos moradores em relação às interferências do turismo no modo de vida da população, ou seja, o que a atividade de turismo de pesca tem trazido de contribuição, assim como o que essa prática tem desencadeado que seja prejudicial à maneira de viver dessas pessoas.

\section{Quadro 2 - Visão dos moradores em relação ao turismo e o modo de vida local}

\begin{tabular}{|l|c|c|}
\hline \multicolumn{1}{|c|}{ Interferências no Modo de Vida Local (Social/Cultural) } & Média & Desvio Padrão \\
\hline $\begin{array}{l}\text { 1- O turismo tem contribuído para uma melhor assistência } \\
\text { sanitária na minha região. }\end{array}$ & 4,618 & 1,18 \\
\hline $\begin{array}{l}\text { 2- Os serviços públicos (saúde, educação, água, luz e } \\
\text { telefone) na minha região têm melhorado em função das } \\
\text { atividades de turismo. }\end{array}$ & 4,671 & 1,18 \\
\hline $\begin{array}{l}\text { 3- Devido ao turismo a infraestrutura da região tem } \\
\text { melhorado. }\end{array}$ & 3,895 & 1,10 \\
\hline $\begin{array}{l}4-\text { Devido ao turismo o acesso à região (disponibilidade } \\
\text { de barcos) tem melhorado. }\end{array}$ & 3,724 & 1,05 \\
\hline $\begin{array}{l}\text { 5- As pessoas da localidade gostam de conhecer os } \\
\text { turistas para ter contato com outras culturas. }\end{array}$ & 2,329 & 1,14 \\
\hline $\begin{array}{l}6-0 \text { turismo favorece a recuperação das nossas tradições } \\
\text { culturais. }\end{array}$ & 2,987 & 1,08 \\
\hline
\end{tabular}




\begin{tabular}{|l|c|c|}
\hline \multicolumn{1}{|c|}{ Interferências no Modo de Vida Local (Social/Cultural) } & Média & Desvio Padrão \\
\hline $\begin{array}{l}7-0 \text { desenvolvimento do turismo na região tem feito com } \\
\text { que se perca a tranquilidade que antes existia. }\end{array}$ & 3,908 & 1,11 \\
\hline $\begin{array}{l}8-\text { O desenvolvimento do turismo tem aumentado o } \\
\text { número de crimes na minha região. }\end{array}$ & 4,632 & 0,96 \\
\hline $\begin{array}{l}9-\text { O encontro com turistas de outros locais do mundo } \\
\text { constitui uma experiência positiva. }\end{array}$ & 2,408 & 0,9 \\
\hline $\begin{array}{l}10-\text { Devido ao turismo os valores religiosos têm } \\
\text { experimentado uma modificação. }\end{array}$ & 4,513 & 0,92 \\
\hline $\begin{array}{l}11-\text { O desenvolvimento do turismo tem aumentado o } \\
\text { consumo de drogas na região. }\end{array}$ & 4,553 & 0,97 \\
\hline $\begin{array}{l}12-\text { Devido ao turismo houve aumento de pessoas } \\
\text { circulando pela região. }\end{array}$ & 2,776 & 0,93 \\
\hline $\begin{array}{l}13-0 \text { turismo favorece a troca de experiências entre } \\
\text { moradores e turistas. }\end{array}$ & 2,461 & 1,09 \\
\hline $\begin{array}{l}14-\text { Quando há muitos turistas, as pessoas da localidade } \\
\text { não se sentem confortáveis na sua própria localidade. }\end{array}$ & 3,645 & 1,04 \\
\hline $\begin{array}{l}15-0 \text { desenvolvimento do turismo na minha região tem } \\
\text { provocado um aumento do trânsito de barcos pelos rios e } \\
\text { igarapés da região. }\end{array}$ & 3,895 & 0,94 \\
\hline $\begin{array}{l}16-0 \text { turismo tem provocado modificações nos hábitos/ } \\
\text { costumes das pessoas. }\end{array}$ & 4,158 & 0,83 \\
\hline $\begin{array}{l}17-0 \text { turismo tem provocado episódios de vandalismo na } \\
\text { região. }\end{array}$ & 4,697 & 0,99 \\
\hline $\begin{array}{l}18-0 \text { turismo tem provocado um maior desenvolvimento } \\
\text { de atividades culturais (festejos). }\end{array}$ & 4,697 & 0,91 \\
\hline $\begin{array}{l}19-\text { Devido ao turismo têm surgido episódios de } \\
\text { prostituição na região. }\end{array}$ & 4,829 \\
\hline $\begin{array}{l}20-0 \text { turismo tem feito com que os episódios de } \\
\text { agressão sexual na região aumentem. }\end{array}$ & 4,921 & 0,81 \\
\hline
\end{tabular}

Fonte: Pesquisa de Campo (2014)

Ressalta-se que esses questionamentos foram os que mais os entrevistados sentiram-se à vontade para responder, nos quais os pesquisadores despenderam mais tempo para ouvi-los e no qual fizeram questão que anotasse todos os seus comentários. Notou-se que a atenção dada pelos pesquisadores, despertou a disposição dos moradores para falar mais abertamente sobre o turismo, diferentemente dos primeiros questionamentos onde foram observados comportamentos mais comedidos por parte dos entrevistados.

Quando questionados sobre a contribuição do turismo para uma melhor assistência sanitária, a média $(4,618)$ mostra que eles discordam. Também discordam $(4,671)$ que os serviços públicos como saúde, educação, água, luz e telefone têm melhorado em função das atividades de turismo. Com relação a essas informações, todos os comentários dos moradores referentes a esses questionamentos evidenciaram que esse descontentamento dos moradores é recorrente, há anos eles buscam auxílio sem nenhuma resposta.

Nogueira (2006), no estudo sobre infraestrutura para o turismo no Baixo Rio Branco, aponta que 96\% dos entrevistados em quatro comunidades da região, inclusive a Vila Terra Preta, responderam que não dispõe de energia, água potável, sistema de esgoto, indicando que esse é um fator complicador para o desenvolvimento do turismo, apesar de existir uma demanda latente. O estudo aponta ainda que 63\% dos entrevistados disseram que os serviços de saúde e segurança pública não são adequados. Quase dez 
anos depois do estudo (NOGUEIRA, 2006), os moradores da localidade ainda não concordam que a infraestrutura, inclusive a acessibilidade (disponibilidade de barcos) da região, tenha melhorado conforme os itens 3 e 4 do Quadro 2.

Quanto à satisfação dos entrevistados em conhecer os turistas, a média $(2,329)$ aponta para um grau de concordância. Apesar do pouco contato entre turistas e moradores, os comentários dos entrevistados consideram positivo esse contato. Os moradores relatam que alguns turistas, antes de embarcar para os locais de pesca, conversam rapidamente com eles e interagem perguntando sobre como é viver em um lugar tão isolado e solicitam permissão para fotografar. Os residentes recordam que já receberam a visita de um grupo na comunidade e que apreciaram bastante esse contato. Concordam $(2,408)$ que o encontro com turistas estrangeiros seja uma experiência positiva, mas comentam que há a barreira do idioma, porém, concordam $(2,461)$ também que o turismo favorece a troca de experiências entre moradores e turistas, como exemplo o comentário de um senhor de 62 anos que declarou depender economicamente do turismo: "[...] o turista chega aqui para pescar trazendo suas ferramentas desenvolvidas, mas ele não sabe em qual parte do rio o peixe está [...], mas nós que trabalhamos com isso a vida toda, sabemos onde e qual peixe encontrar, somente pelo movimento da água ou pela planta que tem perto do local que serve como alimento para o peixe" (respondente do questionário n. 29).

O estudo de Silva e Maia (2008) sobre a avaliação dos benefícios da atividade turística percebidos pelos moradores no Parque Nacional do Catimbau, no município de Buíque-PE, destacou que o envolvimento com a atividade se limitava aos guias, e a maioria dos moradores se encontrava alheia à situação do parque, desse modo, poucos vinham se beneficiando mais diretamente com o turismo. De igual modo, fica evidente uma situação semelhante na região estudada, alguns moradores desconhecem o fato de que a comunidade está inserida em uma área de proteção e que o envolvimento com a atividade turística também se limita aos guias de pesca.

Sobre o turismo favorecer a recuperação das tradições culturais locais, os respondentes concordam parcialmente $(2,987)$, comentam que a vida na comunidade sempre foi a pesca, a caça e essa intimidade com a natureza, conhecer o comportamento dos peixes, por exemplo. Para eles, não foi o turismo que os levou a valorizar isso, enfatizam que a vida, para eles, é isso, embora considerem que com o turismo há uma valorização sim da vida do ribeirinho pescador pelo conhecimento que possui das características da região.

Quanto à afirmação relativa à tranquilidade da região ter sido prejudicada com o advento do turismo, discordam parcialmente $(3,908)$ que isso tenha acontecido, pois as ocorrências de conflitos existentes na região estão relacionadas à disputa pelo uso do recurso para pesca comercial/subsistência/esportiva. Discordam $(4,632)$ que o número de crimes na região tenha aumentado devido ao desenvolvimento do turismo; que tenha aumentado $(4,553)$ o consumo de drogas na região; e que episódios de vandalismo tenham sido provocados $(4,697)$ após o início da atividade. Nesse aspecto os moradores sentem-se privilegiados pela tranquilidade existente no local, comentam que em toda história da comunidade nunca ouviram falar de um crime na Vila Terra Preta, nem antes e nem depois do início da atividade turística.

Quando questionados se os valores religiosos experimentaram alguma modificação devido ao turismo, o grau de concordância foi baixo $(4,513)$, apontando para uma evidente discordância, uma vez que os moradores consideram que o turismo não interfere de maneira nenhuma em suas conviç̧ões religiosas. Concordam parcialmente $(2,776)$ também que devido ao turismo houve aumento de pessoas circulando pela região, comentam que o turista vem para pescar e faz somente isso desde a chegada até a partida. 
Em relação a não se sentir confortável com o grande número de turistas na localidade, os entrevistados discordam parcialmente $(3,645)$ quando questionados sobre esse assunto. Comentam que quando há contato com os visitantes, é bastante agradável e que para eles o desconforto ocorre por não poderem receber o turista na comunidade em razão da falta de infraestrutura.

Quanto ao aumento de trânsito de barcos pelos rios e igarapés da região, os moradores discordam parcialmente $(3,895)$ que isso tenha acontecido devido à atividade turística. Entende-se, pelo fato do isolamento geográfico, que as pessoas que mais transitam pela região são moradores de outras vilas ribeirinhas localizadas no interior e entorno da APA Xeriuini, porém, durante a temporada de pesca esportiva, conforme relatos de alguns moradores, mais barcos circulam pela região. Outros barcos procedem do estado vizinho Amazonas, por vezes, barcos geleiros, visto que a região é desprovida de fiscalização.

Sobre o assunto modificações nos hábitos e costumes locais, os moradores discordam parcialmente $(4,158)$ que o turismo tenha provocado modificações nesse aspecto, porém, alguns moradores comentam que antes do turismo nenhuma pessoa da comunidade usava petrechos de pesca "sofisticados", e depois do turismo pode-se observar o uso desses objetos por parte das pessoas que trabalham como guias de pesca, geralmente ofertados pelos turistas pelo sucesso na pescaria, ofertam também roupas e calçados apropriados para pesca esportiva. Para Rennó e Teixeira (2007, p. 222) a atividade turística pode interferir nos hábitos da comunidade em que se desenvolve, "[...] podendo alterar hábitos e costumes dos moradores e colocando o turista como um polo distribuidor de informações que são assimiladas pelos residentes, afetando suas vidas para melhor ou para pior".

Quando questionados se em função do turismo houve maior desenvolvimento de atividades culturais (festejos) na localidade a média foi alta $(4,697)$, indicando um grau de concordância baixo. Um entrevistado foi enfático: “[...] de todas as vilas do Baixo Rio Branco, a nossa é a mais tranquila, aqui só fazemos festa na igreja" (respondente do questionário n. 41).

O assunto prostituição e agressão sexual foi abordado com bastante prudência, visto que notou-se um comportamento reservado por parte dos entrevistados ao tratar desse tema. Quando questionados se devido ao turismo desenvolvido na região têm surgido episódios de prostituição, a média alta indica um grau de concordância baixo $(4,829)$. Na mesma proporção discordam $(4,921)$ que tenham aumentado os episódios de agressão sexual na localidade e região devido ao turismo.

Em suma, pode-se inferir que, sob a ótica dos moradores entrevistados, as interferências do turismo no modo de vida dos residentes ribeirinhos não têm trazido contribuições como melhorias na assistência sanitária e nos serviços públicos (saúde, educação, comunicação, acessibilidade) da localidade e região. Contudo, têm contribuído para que os moradores sintam-se valorizados em poder empregar seus conhecimentos nessa atividade e viver no local em que sempre viveram, o qual consideram tranquilo sem a agitação e criminalidade dos centros urbanos.

O Quadro 3 exibe as informações sobre a visão dos moradores em relação ao turismo e o meio ambiente. Ao chamar atenção para o assunto meio ambiente, os entrevistados concordam parcialmente $(2,789)$ que o turismo exerce uma forte interferência sobre o meio ambiente da região, sendo percebida de maneira peculiar a cada entrevistado. Foi enriquecedor ao trabalho o registro dos comentários e justificativas das respostas dos moradores na abordagem desse assunto, uns enfatizam o ponto de vista econômico e outros pendem mais para o lado ambiental conservacionista. 
Quadro 3 - Informações sobre a visão dos moradores em relação ao turismo e meio ambiente

\begin{tabular}{|c|c|c|}
\hline Interferências no meio ambiente & Média & Desvio Padrão \\
\hline $\begin{array}{l}1-0 \text { turismo exerce uma forte interferência sobre o meio } \\
\text { ambiente da minha região. }\end{array}$ & 2,789 & 1,57 \\
\hline $\begin{array}{l}2-0 \text { turismo tem contribuído para que se cuide mais do } \\
\text { meio ambiente na minha região. }\end{array}$ & 2,263 & 1,24 \\
\hline 3- Eu participo de ações para preservar o meio ambiente. & 2,263 & 0,91 \\
\hline $\begin{array}{l}\text { 4- Os empresários do turismo de pesca desenvolvem } \\
\text { ações com as pessoas da localidade para preservar o meio } \\
\text { ambiente. }\end{array}$ & 3,079 & 1,46 \\
\hline $\begin{array}{l}\text { 5- } 0 \text { turismo provoca desordem e sujeira nos rios e } \\
\text { igarapés da região. }\end{array}$ & 3,750 & 1,28 \\
\hline 6 - 0 turismo provoca níveis de ruído muito elevados. & 3,434 & 1,16 \\
\hline $\begin{array}{l}7 \text { - Devido ao turismo tem aumentado o volume de lixo nos } \\
\text { espaços da comunidade. }\end{array}$ & 3,829 & 0,90 \\
\hline
\end{tabular}

Fonte: Pesquisa de Campo (2014)

Um desses comentários foi que a pesca para o turismo (pesca esportiva) ajuda a preservar os recursos: "[...] hoje, nós pensamos duas vezes em matar o peixe, ele vale mais estando vivo do que morto, pensamos em cuidar mais do ambiente para garantir a satisfação do turista que vem para pescar" (respondente do questionário n. 55). Após a criação da APA e do advento do turismo, a pesca profissional/comercial foi proibida, conforme o Decreto n. 25 de 08 de dezembro de 1999.

Nogueira e Ghedin (2010, p. 794) identificaram a opinião de moradores da região do Baixo Rio Branco que fazem a relação dos rendimentos conseguidos por meio da pesca esportiva, "[...] um quilo de peixe quando fisgado por um pescador esportivo (que pesa, fotografa e devolve o indivíduo vivo para o ambiente natural), podendo ser pescado novamente pelo mesmo turista pescador ou por outro". Já na pesca artesanal o peixe é retirado do ambiente natural e tem seu valor comercial menor do que na pesca esportiva, “[...] afirmam que $10 \mathrm{~kg}$ de peixe na pesca esportiva, poderá lhes render aproximadamente $\mathrm{R} \$ 200,00$ por dia, enquanto que na pesca artesanal a mesma quantidade em kg lhes renderá apenas R 70,00 por dia”. Em alguns dos comentários registrados, notaram-se posturas semelhantes aos identificados pelas autoras acima mencionadas.

Todavia, em uma postura mais conservacionista, alguns entrevistados mencionaram o risco de sobrevivência do peixe após a captura/soltura pelo turista pescador, na modalidade de pesca esportiva em que é obrigatória a devolução do peixe às águas do rio. Aguiar e Gomes (2013) mostram o relato de um morador da região do Baixo Rio Branco sobre os peixes doentes encontrados por pescadores quando estes saem para pesca de subsistência, o morador comenta que o anzol (isca artificial usada na pesca esportiva) maltrata o peixe, rasga parte de sua boca e este fica dias sem poder se alimentar, muitas vezes é encontrado com a cabeça grande e o corpo fino, devido à falta de alimento.

O estudo de Barton (2002) mostra que após estímulos estressantes, o organismo do peixe pode evocar respostas não específicas podendo chegar a um desequilíbrio homeostático; se a situação estressante for severa e de duração longa o peixe não será capaz de recuperar a sua homeostase. 
Se por um lado o turismo de pesca na região tem ajudado na preservação dos rios, da fauna e flora, por outro há que se pensar em medidas que minimizem essas interferências da prática de pesca, quanto aos equipamentos permitidos nessa modalidade de pesca, causadas à ictiofauna, para que se possa pensar na preservação e conservação dos recursos em longo prazo.

Quando questionados se o turismo tem contribuído para que se cuide mais do meio ambiente, a média $(2,263)$ aponta uma concordância, assim como para a participação em ações para preservar o meio ambiente. Concordam parcialmente $(3,079)$ que os empresários do turismo de pesca desenvolvam ações para a preservação do meio ambiente com a comunidade.

Ao serem perguntados se a atividade turística provoca desordem e sujeira nos rios e igarapés da região, assim como se o turismo provoca níveis de ruídos muito elevados e ainda se houve aumento do volume de lixo nos espaços da comunidade, as médias calculadas $(3,750 ; 3,434)$ revelam uma oscilação entre a concordância parcial e a discordância parcial, o que foi justificado pelos comentários registrados no ato da entrevista que indicam incerteza por parte dos moradores ao responder esses questionamentos.

Sobre desordem e sujeira, comentam que a empresa atuante é bastante cuidadosa nesse quesito, mas não sabem responder sobre o destino dos resíduos derivados do atendimento ao turista nos locais de pesca; alguns sugeriram que é enterrado em algum local. Com relação aos níveis de ruídos elevados, comentam que há mais barcos circulando pela região, pois para cada dois pescadores é disponibilizado um barco equipado com motor, porém, para que se realize a atividade de pesca o barco fica parado e o motor é silenciado. A respeito do aumento no volume de resíduos sólidos nos espaços da comunidade devido ao turismo, a média $(3,829)$ aponta uma discordância parcial. Os entrevistados se reservam em conversar sobre o assunto, relatam que enterram ou queimam os resíduos.

Observou-se uma quantidade moderada de resíduos sólidos nos espaços da comunidade, aparentemente derivada de ações dos próprios moradores, não tendo relação com a atividade turística. Quanto a esse assunto, foram observadas pelos pesquisadores algumas atitudes inapropriadas por parte dos moradores, por exemplo, as duas registradas no diário de anotações: uma pessoa foi observada quando jogou uma sacola plástica no rio sem a menor preocupação, com o barco em movimento como se fosse algo muito natural e outro exemplo é o da pessoa que despejou no rio uma fralda descartável usada. Essas atitudes indicam a falta de sensibilidade no uso do recurso hídrico, que para essas pessoas é a única via de acesso para suas casas e a fonte do seu principal alimento, o peixe.

Ramos (2012, p. 110), que investigou a qualidade ambiental a partir da identificação de interferências ambientais decorrentes do turismo em três lagoas costeiras do Sul do Brasil, aponta que os resíduos sólidos dispostos em locais inadequados e a inexistência de coleta é algo que constantemente ocorre e se nota em áreas naturais que são visitadas por turistas, além de que essa condição pode prejudicar o meio ambiente (recurso hídrico, fauna e flora) e também torna-se um risco à saúde humana. Para o autor, “[...] os resíduos presentes em um local turístico podem prejudicar a experiência do turista, por meio da diminuição da qualidade estética da paisagem devido a sua presença”.

Apesar da não permanência do turista nos espaços da comunidade, esta é a porta de entrada para os locais de pesca, considerando que o primeiro contato do visitante com a região, após a vista aérea, acontece no momento do desembarque deste na comunidade.

Um aspecto ambiental que foi observado pelos pesquisadores com bastante relevância para futuras discussões, é o fato da inexistência de saneamento básico sujeitar os moradores a utilizarem fossas rudi- 
mentares (próximo à margem do rio) para despejo de esgoto sanitário, o que pode acarretar contaminação das águas, além do lançamento de águas residuárias, sem tratamento, diretamente no rio.

Existem outros pontos a serem abrangidos em uma análise das interferências ambientais na região estudada, por exemplo, a estrutura instalada na região para o atendimento ao turista (hospedagem, alimentos e bebidas, lavanderia, barcos, etc.), a capacidade de carga das zonas de pesca e os equipamentos usados para a captura dos peixes, porém, não foram considerados neste estudo por exigir um embasamento teórico específico à temática assim como visita ao local. No caso deste estudo o enfoque se deu na comunidade.

\section{Participação e envolvimento da comunidade em relação ao turismo de pesca}

Apesar de constar no documento oficial Evolução do Processo de Criação da APA Xeriuini - Resumo analítico do diagnóstico socioeconômico ambiental que a criação da unidade de conservação Área de Proteção Ambiental Xeriuini, em 1999, foi precedida de consulta aos moradores das comunidades em seu interior, e que estes a referendaram na condição de beneficiários diretos (CARACARAÍ, 2000), foi constatado que alguns dos moradores da Vila Terra Preta entrevistados desconheciam a informação de que a comunidade está inserida na referida UC até recente data.

Para averiguar se a comunidade estudada está envolvida na atividade que vem acontecendo há mais de uma década, foi perguntado sobre a participação em associações ou cooperativas e o conhecimento da legislação específica para o turismo de pesca na APA, além da perspectiva dos moradores para a atividade. O Quadro 4 exibe as informações levantadas.

Sobre a existência de órgãos públicos para tratar assuntos relacionados ao turismo os entrevistados concordam parcialmente $(2,645)$ que existem órgãos específicos responsáveis pela atividade na região. Também concordam parcialmente $(2,776)$ que existem leis específicas para o turismo de pesca na região. Em seus comentários, revelaram que já foram realizadas algumas palestras para falar sobre o turismo, porém, geralmente, o modo de se expressar das pessoas responsáveis é de difícil compreensão. Entende-se que, por se tratar de assuntos referentes à legislação, os termos empregados para essa comunicação sejam de abrangência técnica, dificultando o entendimento por parte dos ribeirinhos.

\section{Quadro 4 - Informações sobre a participação e envolvimento na atividade turística}

\begin{tabular}{|l|c|c|}
\hline \multicolumn{1}{|c|}{ Participação e Envolvimento } & Média & Desvio Padrão \\
\hline $\begin{array}{l}\text { Existem órgãos públicos responsáveis por assuntos de } \\
\text { turismo na minha região. }\end{array}$ & 2,645 & 1,48 \\
\hline $\begin{array}{l}\text { Existem leis específicas para a atividade de turismo de } \\
\text { pesca na região. }\end{array}$ & 2,776 & 1,43 \\
\hline $\begin{array}{l}\text { A prefeitura e os responsáveis políticos estão trabalhando } \\
\text { para promover o turismo. }\end{array}$ & 4,039 & 1,26 \\
\hline $\begin{array}{l}\text { O turismo de pesca tem na atualidade uma grande } \\
\text { importância para o meu estado. }\end{array}$ & 3,368 & 1,56 \\
\hline $\begin{array}{l}\text { Eu apoio o desenvolvimento do turismo de pesca na minha } \\
\text { região. }\end{array}$ & 1,974 & 1,06 \\
\hline Eu tenho trabalho garantido na temporada de pesca. & 3,592 & 1,81 \\
\hline
\end{tabular}




\begin{tabular}{|c|c|c|}
\hline Participação e Envolvimento & Média & Desvio Padrão \\
\hline $\begin{array}{l}\text { Eu participo da Associação ou da Cooperativa de } \\
\text { Pescadores. }\end{array}$ & 4,447 & 2,05 \\
\hline $\begin{array}{l}\text { Eu participo de Associação ou de Cooperativa de } \\
\text { trabalhadores do turismo (piloteiro, camareira, cozinheira, } \\
\text { garçom, etc.) }\end{array}$ & 5,658 & 0,95 \\
\hline $\begin{array}{l}\text { Eu conheço as leis que regulamentam a atividade de } \\
\text { turismo de pesca na minha região. }\end{array}$ & 4,158 & 1,25 \\
\hline $\begin{array}{l}\text { Eu participo de atividades propostas pelo poder público } \\
\text { para discutir sobre o turismo de pesca na minha região. }\end{array}$ & 4,434 & 1,27 \\
\hline $\begin{array}{l}\text { O turismo terá papel fundamental no desenvolvimento da } \\
\text { minha região. }\end{array}$ & 2,421 & 1,33 \\
\hline
\end{tabular}

Fonte: Pesquisa de Campo (2014)

Ao serem perguntados se a prefeitura e os responsáveis políticos estão trabalhando para promover o turismo, a média $(4,039)$ indica uma discordância parcial em relação a esse assunto. Os entrevistados desabafam em seus relatos que em épocas eleitorais um número elevado de políticos visita a comunidade, mas passado esse período não recebem nenhuma atenção. Sobre as ações da prefeitura, os comentários são bastante pessimistas, a maior crítica se refere à saúde, educação e à falta de fiscalização.

Foi identificada uma atitude bastante passiva em relação ao descaso do poder público na assistência da região e na ausência de ações em relação ao turismo, porém, os moradores se mostram inconformados com a oferta de apenas alguns empregos temporários gerados pelas empresas de turismo.

Vitório (2010) constatou, ao investigar a percepção dos moradores de Caracaraí-RR em relação ao desenvolvimento do turismo, que $85,37 \%$ dos entrevistados responderam que não conheciam o trabalho do governo local a favor do turismo na localidade e $91,46 \%$ disseram não participar de alguma ação proposta pelo governo a favor do turismo na localidade. A autora destacou que os sujeitos que declararam não conhecer o trabalho do governo local e não participar de alguma ação proposta pelo governo, bem como não participar de algum grupo organizado que considere propostas de desenvolvimento do turismo na localidade, possuíam o nível de escolaridade elevado e descartou a possibilidade desse não conhecimento e dessa não participação estarem relacionados à falta de instrução e informação, evidenciando certo desinteresse do poder público em levar suas ações ao conhecimento da população. No caso da Vila Terra Preta, pode-se deduzir que além do nível de escolaridade baixo dos moradores, essa interação com o poder público também é dificultada devido ao isolamento, porém, essa situação não minimiza a responsabilidade do órgão público em dar mais assistência ao povo ribeirinho.

Quando questionados se consideram que o turismo tem na atualidade uma grande importância para o estado, os respondentes concordam parcialmente $(3,368)$. Defendem que se houvesse mais atenção por parte do governo, quanto à fiscalização na região, seria um auxílio bastante proveitoso. Comentam que pelo fato de não haver fiscalização eles são os maiores prejudicados quanto aos benefícios do turismo, entretanto, concordam $(1,974)$ sobre o seu apoio ao desenvolvimento do turismo de pesca na região.

Aguiar e Gomes (2013) mostram o relato de uma pesquisadora da Universidade Estadual de Roraima (UERR) sobre a ineficiência da fiscalização em áreas amazônicas, como no caso da APA Xeriuini, onde é autorizada apenas pesca nas modalidades subsistência e esportiva (FEMACT, 2011). Segundo a pesquisadora da UERR, o morador pescador usa técnicas artesanais que causam menor interferência na população de peixes, pescando para sua sobrevivência. Entretanto os barcos pesqueiros vindos do estado 
do Amazonas, que entram clandestinamente no interior da UC devido à ausência de fiscalização, utilizam tecnologias para capturas muito mais eficientes e com a finalidade de comercialização, ficando o ribeirinho residente no interior da APA, que tem todo o cuidado de selecionar o peixe para a atividade turística e o peixe para a sua alimentação, como maior prejudicado.

É fato constatado que o turismo gera empregos para as pessoas da localidade, mesmo que de modo sazonal. Porém ao serem perguntados se os moradores têm trabalho garantido na temporada de pesca, os entrevistados discordam parcialmente $(3,592)$, e referem-se à quantidade de ofertas que não atende a todos que desejam trabalhar na atividade. Nogueira e Ghedin (2010) ressaltam que na região do Baixo Rio Branco a principal atividade exercida pelos moradores é a pesca artesanal, o que lhes confere um grande conhecimento sobre os rios da região e a sua ictiofauna, porém, não possuem os conhecimentos técnicos necessários para lidar com os turistas. Essa situação acarreta uma postura de ponderação por parte da empresa em considerar esse paradoxo na organização da atividade. No entanto, há obrigatoriedade em captar $80 \%$ da mão de obra nas comunidades inseridas na UC.

Perguntados se participam de Associação ou Cooperativa de pescadores, os respondentes discordam parcialmente $(4,447)$, notou-se que alguns moradores confundiam-se ao responder esse questionamento, pois na localidade não existem associações/cooperativas de pescadores e nem de trabalhadores do turismo, e sim uma associação de produtores rurais, a qual o seu presidente responde também como líder da comunidade. Em conversa com o líder comunitário, verificou-se que, por meio dessa associação, resolvem algumas questões formais referentes a repasse de valores pela empresa atuante na APA e formalizam solicitações a órgãos públicos sobre agricultura, nenhum assunto sobre a organização do turismo na comunidade é tratada nas reuniões dessa associação. De posse dessa informação ficou evidente o porquê da discordância total $(5,658)$ em relação à afirmação quanto a participação em associação ou cooperativa de trabalhadores do turismo (piloteiro, camareira, cozinheira, garçom, etc.).

No assunto sobre conhecer as leis e normas que regulamentam a atividade do turismo de pesca na região a discordância parcial $(4,158)$ verificada deixa claro o afastamento da comunidade da possibilidade de estar mais envolvida e mais participativa nas decisões sobre a atividade na sua localidade.

Quando questionados se participam de atividades propostas pelo poder público para discutir o turismo de pesca na região, discordam parcialmente $(4,434)$ e comentam que recentemente a Secretaria Municipal de Meio Ambiente e Turismo enviou agentes à comunidade para falar sobre a unidade de conservação, mas que em todos esses anos desde que se iniciou a atividade turística, nada em relação ao uso dos recursos para o turismo foi consultado ou informado de maneira compartilhada com a comunidade, por vezes, apenas alguns moradores tomam conhecimento de informações isoladamente. Mesmo diante desse quadro que mostra a população sobremaneira alheia a acontecimentos e decisões tomadas para o lugar onde vivem, os moradores concordam $(2,421)$ de maneira otimista que o turismo ainda terá papel fundamental no desenvolvimento da região.

Mota, Vianna e Anjos (2013, p. 163) em seus estudos de casos brasileiros constataram que "a visão e os interesses dos setores público, privado e comunidade local precisam encontrar seus pontos convergentes" para que seus esforços e interferências sejam em "prol de resultados satisfatórios para todos os atores que interagem com a destinação turística".

Nota-se que a única relação dos moradores com a atividade se dá por meio dos serviços prestados como guias de pesca, cozinheira/camareira, "fiscal" e auxiliar de serviços gerais e ainda de modo informal, 
ou seja, sem registro na Carteira de Trabalho, sem direito previdenciário e FGTS e com jornada de trabalho excessiva. O fato de não estarem organizados em associações ou cooperativas específicas, os torna sujeitos a condições de trabalhos extenuantes. Como foram considerados por Nogueira e Ghedin (2010), esses trabalhadores (guias de pesca) exercem suas atividades laborais em condições insalubres, sujeitos a acidentes de trabalho, pois realizam tarefas como: retirar e colocar iscas artificiais; desengatar iscas; auxiliar na retirada dos anzóis da boca dos peixes; cuidar da alimentação, bebidas e equipamentos dos turistas; organizar os barcos; e fazer o planejamento para o dia de pesca. Tudo isso faz com que a jornada de trabalho desses guias seja superior a 10 horas diárias.

Após essas análises é possível afirmar que a comunidade de Vila Terra Preta não participa e também não está sendo envolvida em discussões a respeito da atividade turística na região em que está inserida. É notório que a articulação da atividade está restrita aos gestores (poder público) e aos empresários, ficando a comunidade, além de excluída desse processo, vulnerável aos efeitos negativos das interferências e deixando de aproveitar os benefícios destas.

\section{CONSIDERAÇÕES FINAIS}

Com o propósito principal de analisar as interferências da atividade turística de pesca no Baixo Rio Branco, sob a ótica da comunidade de Terra Preta, pode-se dizer que o objetivo geral foi alcançado, revelando a opinião dos moradores entrevistados bem como as suas perspectivas em relação ao turismo de pesca e as interferências no modo de vida desses moradores.

Os resultados revelaram a necessidade de organização da liderança política no âmbito da gestão municipal com ênfase no comprometimento e responsabilidade socioambiental, conforme os outorga a legislação. Também a necessidade da criação de ambientes de discussão e organização de iniciativa da população local, por exemplo, Associação ou Cooperativa para que possam requerer melhorias para as condições de trabalho de seus contratantes. Às empresas compete valorizar o trabalho dos guias de pesca contratados, pois muito mais do que a prestação do serviço, estes estão disponibilizando seus conhecimentos a respeito dos rios e dos peixes, sem os quais seria mais difícil a obtenção de sucesso nas pescarias, que é o produto maior das empresas turísticas.

Nessa direção, o turismo de base comunitária, como modelo de gestão, se mostra uma alternativa para a inclusão da comunidade no processo de planejamento, organização e gestão da atividade, pois por meio desse modelo é possível visualizar o envolvimento efetivo dos moradores, atribuindo respeito às manifestações culturais próprias da região do Baixo Rio Branco e valor adequado aos serviços prestados pela comunidade considerando o conhecimento que ela detém sobre o meio ambiente local. Com a criação de uma cooperativa comunitária, seria possível garantir postos de trabalho e renda, como comércio ou aluguel de equipamentos para pesca, produção de artesanato local, alimentos e até hospedagem para o turista que tivesse preferência por ficar na comunidade, proporcionando emprego para mais pessoas e em diferentes funções.

Este estudo traz contribuição para a discussão sobre as relações existentes entre a atividade turística, as comunidades e o meio ambiente, bem como as interferências resultantes dessa relação, colocando o turismo de base comunitária como alternativa de gestão para comunidades dispostas a trabalhar com essa alternativa. Também contribui para discussões sobre a importância de valorizar a visão da comunidade 
sobre a atividade e suas interações socioambientais, e que esta pode auxiliar na mitigação das interferências negativas e na intensificação das interações positivas.

Foi possível observar, durante a realização deste trabalho, a carência de estudos sobre o turismo de pesca, constatando poucas publicações científicas sobre o assunto. Ressalta-se que a metodologia utilizada foi bastante eficiente desde a definição dos indicadores que auxiliaram na elaboração do instrumento de pesquisa às estratégias e ações para a coleta de dados, garantindo a confiabilidade da pesquisa.

Apesar dos avanços aqui obtidos em relação ao entendimento desse fenômeno, surgem questionamentos que podem ser desdobrados em futuras pesquisas: a) Como a comunidade pode se mobilizar para iniciar seu envolvimento nas discussões sobre o turismo na região? b) $\mathrm{O}$ empresariado tem interesse em ser parceiro nas ações de planejamento? c) Quais fatores interferem na organização do poder público local?

Enfim, acredita-se que com a disseminação dos resultados obtidos e sistematização das informações, outros pesquisadores venham a desenvolver o interesse em pesquisas na região e na produção de conhecimento científico sobre o tema.

\section{REFERÊNCIAS}

AGUIAR, E.; GOMES, O. Xeriuini. Documentário, Caracaraí, RR, 2013.

BARTON, B. A. Stress in fishes: a diversity of responses with particular eference o changes in circulating corticosteroids. Integrative and Comparative Biology, v. 42, p. 517-525, 2002. Disponível em: 〈http:// icb.oxfordjournals.org/content/42/3/517.full.pdf+html. Acesso em: 17 ago. 2014.

BRASIL. Lei n. 11.959, de 29 de junho de 2009. Dispõe sobre a Política Nacional de Desenvolvimento Sustentável da Aquicultura e da Pesca. Disponível em: 〈http://www.planalto.gov.br/ccivil_03/_ at02007-2010/2009/Lei/L11959.htm>. Acesso em: 07 mar. 2013.

. Lei n. 11.771 , de 17 de setembro de 2008. Define as atribuições do Governo Federal no planejamento, desenvolvimento e estímulo ao setor turístico. Disponível em: 〈www.planalto.gov.br/ ccivil_03/_ato2007-2010/2008/lei/l11771.htm〉. Acesso em: 14 dez. 2013.

. Ministério do Turismo. Turismo de Pesca: orientações básicas. Ministério do Turismo, Secretaria Nacional de Políticas de Turismo, Departamento de Estruturação, Articulação e Ordenamento Turístico, Coordenação-Geral de Segmentação. - 2. ed. - Brasília: Ministério do Turismo, 2010. Disponível em: 〈http://www.turismo.gov.br/export/sites/default/turismo/o_ministerio/publicacoes/downloads_ publicacoes/Turismo_de_Pesca_Versxo_Final_IMPRESSxO_.pdf〉. Acesso em: mar. 2013.

Ministério do Turismo. Marcos Conceituais. Secretaria Nacional de Políticas de Turismo, Departamento de Estruturação, Articulação e Ordenamento Turístico, Coordenação-Geral de Segmentação. Disponível em: 〈http://www.turismo.gov.br/export/sites/default/turismo/o_ ministerio/publicacoes/downloads_publicacoes/Marcos_Conceituais.pdf $\rangle.$ Acesso em: mar. 2013.

BURSTYN, I.; BARTHOLO, R.; DELAMARO, M. Turismo para quem?: sobre caminhos de desenvolvimento e alternativas para o turismo no Brasil. 2009, p. 86. In: BARTHOLO, R.; SANSOLO, D. G.; BURSZTYN, I. (Org.). Turismo de Base Comunitária: diversidade de olhares e experiências brasileiras. Rio de Janeiro: Letra e Imagem, 2009. 
CAMARGO, H. P. P. V; MACHIAVELLI, M. S.; RAMOS, B. V. C. Interferências na localidade: considerações sobre turismo, cultura e descaracterização. Anais [...] VIII Seminário da Associação Nacional de Pesquisa e Pós-Graduação em Turismo. Univali - Balneário Camboriú/SC, 2011.

CARACARAÍ. Prefeitura Municipal. Decreto-Lei n. 25, de 08 de dezembro de 1999. Dispõe sobre a criação da Área de Proteção Ambiental Xeriuini e dá outras providências.

. Prefeitura Municipal. Lei n. 378, de 18 de novembro de 2002. Institui a licença de pesca da Área de Proteção Ambiental Xeriuini e dá outras providências.

. Departamento de Meio Ambiente e Turismo. Evolução do Processo de Criação da APA Xeriuini - Resumo analítico do diagnóstico socioeconômico ambiental. Dematur, Caracaraí, 2010.

Secretaria Municipal de Planejamento. Informações Socioeconômicas do Município de Caracaraí - RR, Caracaraí, 2010.

- Secretaria Municipal de Saúde. Relatório Mensal do Sistema de Informação de Atenção Básica. PSF Ribeirinho, SIAB, outubro, 2013.

COOPER, C. et al. Turismo, princípios e prática. Trad. Roberto Cataldo Costa, 2. ed. - Porto Alegre: Bookman, 2001.

CORIOLANO, L. N. M. T. O turismo comunitário do Nordeste brasileiro. In: BARTHOLO, R.; SANSOLO, D. G.; BURSZTYN, I. (Org.). Turismo de Base Comunitária: diversidade de olhares e experiências brasileiras. Rio de Janeiro: Letra e Imagem, 2009.

DALL'AGNOL, S. Laguna como destino turístico: o pensar dos residentes. Dissertação de Mestrado, Caxias do Sul: UCS, 2009.

FORTUNATO, R. A.; SILVA, L. S. Os conflitos em torno do turismo comunitário na Prainha do Canto Verde (CE). Revista Brasileira de Ecoturismo, São Paulo, v. 6, n.1, jan/abr- 2013, p.123-138.

GOODWIN, H.; SANTILLI, R. Community-Based Tourism: a success? ICRT \& GTZ., 2009. Disponível em: 〈http://www.haroldgoodwin.info/uploads/CBTaSuccessPubpdf.pdf〉 Acesso em: 22 mar. 2013.

IRVING, M. A. Reinventando a reflexão sobre turismo de base comunitária: inovar é possível? In: BARTHOLO, R.; BURSZTYN, I.; SANSOLO, D. (Org.). Turismo de Base Comunitária: diversidade de olhares e experiências brasileiras. Rio de Janeiro: Letra e Imagem, 2009.

ISA - INSTITUTO SOCIOAMBIENTAL. Diversidade socioambiental de Roraima: subsídios para debater o futuro sustentável da região / [organização Ciro Campos]. - 2. ed. revisada, São Paulo: Instituto Socioambiental, 2011.

KÖECHE, J. C. Fundamentos de metodologia científica: teoria da ciência e iniciação à pesquisa. 29. Ed. - Petrópolis, RJ: Vozes, 2011.

MACHADO, A. L. M.; BAZOTTI, L. S.; VIANNA, S. L. G. A certificação no turismo de aventura: uma análise do impacto no destino Serra Gaúcha. Caderno Virtual do Turismo, v. 14, n. 2, p. 101-116, 2014.

MALDONADO, C. Pautas metodológicas para el análisis de experiencias de turismo comunitário. 2005. Disponivel em: 〈http://www.ilo.org/empent/Publications/WCMS_117525/lang--es/index. htm〉. Acesso em: mar. 2013.

MARTOS, H. L.; MARTOS, M. Y. H. G. Turismo de Pesca. In: TRIGO, L. G. G. Análises regionais e globais do turismo brasileiro. São Paulo: Rocca, 2005. 
MOTA, K. C. N.; VIANNA, S. L. G.; ANJOS, F. A. Competitividade das destinações turísticas: estudo de casos brasileiros. São Paulo: Atlas, 2013.

NOGUEIRA, E. M. Turismo no Baixo Rio Branco: diagnóstico de capacitação e infraestrutura. Norte Científico - v. 1, n. 1 dezembro de 2006. Disponível em: 〈http://reitoria.ifrr.edu.br/SISTEMAS/ revista/index.php/revista/article/view/43〉. Acesso em: jul. 2014.

NOGUEIRA, E. M.; GHEDIN, L. M. A pesca esportiva como suporte para o turismo de base local no Baixo Rio Branco no Estado de Roraima. Anais [...] XI ENCONTRO NACIONAL DE TURISMO COM BASE LOCAL Turismo e Transdisciplinaridade: novos desafios. Niterói - RJ, 2010.

OLIVEIRA, S. D. F. A.; TEIXEIRA, R. M. Contribuição socioeconômica do setor privado na atividade turística: o caso de Canindé de São Francisco - SE. Turismo - Visão e Ação, v. 7, n. 2 p. 291-310 maio/ ago. 2005 .

OMT - Organização Mundial do Turismo. Guia de Desenvolvimento do Turismo sustentável. Porto Alegre: Bookman, 2003.

POUPART, J. et al. A Pesquisa Qualitativa: enfoques epistemológicos e metodológicos. Tradução de Ana Cristina Nasser. - Petrópolis, RJ: Vozes, 2008.

RAMOS, B. V. C. Interferências do uso turístico na qualidade ambiental de lagoas costeiras do litoral norte do Rio Grande do Sul. Dissertação de Mestrado, Caxias do Sul: UCS, 2012.

RENNÓ, L. C.; TEIXEIRA, D. J. 0 impacto do turismo nos hábitos de consumo de uma comunidade de pequeno porte. Turismo - Visão e Ação, v. 9, n. 2, p. 217-232 maio /ago. 2007

RUSCHMANN, D. V. M. Turismo e Planejamento Sustentável: a proteção do meio ambiente. 4. ed. Campinas: Papirus, 1999.

SANTANA, A. Antropologia do turismo. Analogias, encontros e relações. São Paulo: Aleph, 2009.

SILVA, J. H.; MAIA F. B. A. 0 turismo no parque nacional do catimbau: avaliação dos benefícios da atividade percebidos pelos moradores. Turismo - Visão e Ação - Eletrônica, v. 10, n. 2. p. 204-220, mai/ago. 2008

SILVEIRA, M. A. T. Planejamento Territorial e Dinâmica Local: bases para o turismo sustentável. In: RODRIGUES, A. B. (Org.). Turismo e desenvolvimento local. São Paulo: Hucitec, 1999.

SPERB, M. P.; TEIXEIRA, R. M. A sustentabilidade ambiental do turismo na llha do Mel, PR: perspectiva dos gestores públicos. Turismo - Visão e Ação, v. 8, n. 3, p. 437-453, set. /dez. 2006

VASCONCELOS, F. P.; CORIOLANO, L. N. M. T. Impactos Socioambientais no Litoral: um foco no turismo e na gestão integrada da zona costeira no estado do Ceará/Brasil. Revista de Gestão Costeira Integrada 8(2):259-275, 2008.

VITÓRIO, L. S. Percepção da comunidade local em relação ao desenvolvimento da atividade turística no município de Caracaraí - Roraima. Monografia, Boa Vista: UERR, 2010.

WWF-BRASIL. Certificação em Turismo: lições mundiais e recomendações para o Brasil. SALAZAR, S. (Coord.). Brasília: WWF-Brasil, 2001. 